\title{
Population dynamics of potential bioagents of mustard aphid, Lipaphis erysimi (Kaltenbach) on different cultivars of rapeseed-mustard
}

\author{
Richa Varshney $^{1 *}$, R. R. Rachana ${ }^{1}$ and R. S. Bisht ${ }^{2}$ \\ ${ }^{1}$ Department of Insect Systematics, National Bureau of Agricultural Insect Resources, Bangalore-560024 \\ (Karnataka), INDIA \\ ${ }^{2}$ Department of Entomology, Govind Ballabh Pant University of Agriculture \& Technology, Pantnagar-263145 \\ (Uttarakhand), INDIA \\ *Corresponding author. E-mail: richavarshney84@gmail.com
}

Received: April 5, 2016; Revised received: October 6, 2016; Accepted: January 2, 2017

\begin{abstract}
Field experiment was conducted to study the population dynamics of potential bioagents of mustard aphids on 9 different cultivars which included: Brassica alba cv. PSB-I, Eruca sativa Mill cv. T-27, Brassica campestris cv. BSH-I, Brassica napus cv. Sheetal, B. carinata Braun cv. CCN-06-1, B. juncea L. cv. Varuna, B. nigra Koch. cv. PBR-I, Brassica campestris cv.YST-151 and Brassica campestris cv. PT-30. Population of aphid and natural enemies was recorded at weekly intervals. The results indicated that the first appearance of coccinellids and syrphids has been observed during $4^{\text {th }}$ standard week, which gradually build up population and attained peak during $9^{\text {th }}$ (pooled mean 1.42 coccinellids/ plant and 0.122 syrphid larva/plant) and $8^{\text {th }}$ standard week (pooled mean 3.96 coccinellids/plant and 0.228 syrphid larva/plant) in 2008-09 and 2009-10 respectively, followed by a declining trend in the following weeks. Similarly first appearance of parasitization has been found to occur from $4^{\text {th }}$ standard week followed by a gradual increase in the following weeks with maximum parasitization on PT-30 (33.32\%) and BSH-1 (35.25\%) during 2008-09 and 2009-10 respectively. Correlation between abiotic factors and these natural enemies was also studied. It has been observed that with the increase of aphid population the population of natural enemies also increased. The population dynamics of mustard aphids and its natural enemies varied according to climatic situations and between host plant species. So by computing population trends of both natural enemies and aphids with meterological records would generate information on relative abundance and would certainly help in formulating sound pest management strategies against mustard aphid.
\end{abstract}

Keywords: Coccinellids, Diaeretiella rapae, Lipaphis erysimi, Percent parasitization, Syrphids

\section{INTRODUCTION}

Brassicas are an important group of crops which have great economic importance all over the world (Trdan $e t$ al., 2005; Suwabe et al., 2006; Hong et al., 2008; Golizadeh et al., 2009). They can be grown as vegetables and oilseeds (Kumar, 2015). In India, under the name rapeseed and mustard, three cruciferous members of Brassica species are cultivated; B. juncea (Indian mustard or commonly called rai) being the chief oil-yielding crop, while three ecotypes of $B$. rapa ssp. oleifera, viz. brown sarson, yellow sarson, toria and $B$. napus are grown to a limited extent (Bhatia et al., 2011). Rapeseed mustard accounts for nearly onethird of the oil produced in India, making it the country's key edible oilseed crop. In India, during 2013-14 area and production of rapeseed mustard was 6.70 million hectare and 7.96 million tons respectively (ASG, 2014).

Among the insect pests, the mustard aphid, Lipaphis erysimi (Kaltenbach) (Hemiptera: Aphididae) is a serious threat to successful cultivation of oilseed Brassicas in India (Kumar et al., 2011; Atri et al., 2012) and it infest the crop right from seedling stage to maturity (Singh, 2013). For the management of mustard aphids at present farmers spray systemic insecticides which not only pollute the environment but also kill several natural enemies which have been reported naturally in mustard ecosystem.. Several natural enemies of mustard aphids have been reported from time to time. Among the several bio-agents, syrphid flies (S. confrater, S.balteatus and I. scutellaris) and lady bird beetle, C. septempunctata are the important entomophagous predators and in field they are observed as an efficient predator of L. erysimi (Singh et al., 2012; Singh, 2013). Diaeretiella rapae (Mc Intosh) (Hymenoptera: Aphidiinae) is an important primary, polyphagous parasitoid of many aphid species throughout the world (Kumar 2015). In India, the rate of parasitism of mustard aphid, by D. rapae on rape-seed mustard crop varied from $20 \%$ to $51 \%$ in Himachal Pradesh to 60 97\% in Maharashtra (Dogra et al., 2003; Kumar, 2015). The population dynamics of both mustard aphid as well as its associated bioagents with particular reference to the agro-ecological conditions has an added significance in pest management. The knowledge of 
L. erysimi-natural enemies' relationships will also help to improve conservation biological control strategies as many of the natural enemies are present in mustard ecosystem. The population dynamics of mustard aphids and its natural enemies vary according to climatic situations and between host plant species. Keeping the above view in mind, the ecological study of bioagents viz. coccinellids, syrphids and Diaeretiella rapae of mustard aphid on 10 different varieties of mustard was conducted with the objective to generate information on the suitability of these bioagents to reduce aphid population and to know whether resident natural enemies can be used for conservation biological control of this pest.

\section{MATERIALS AND METHODS}

The seasonal occurrence of bioagents of Lipaphis erysimi (Kaltenbach) on oleiferous Brassicas was carried out at G.B. Pant University of Agriculture and Technology, Pantnagar, Uttarakhand during rabi season, for two consecutive years, 2008-09 and 2009-2010. Experiments were laid down in Randomized Block Design (RBD) with three replications. 9 oilseed Brassica species viz. Brassica alba (syn. Sinapis alba) cv. PSB-I, Eruca sativa Mill cv. T-27, Brassica campestris cv. BSH-I, Brassica napus cv. Sheetal, B. carinata Braun cv. CCN-06-1, B. juncea L. cv. Varuna, B. nigra Koch. cv. PBR-I, Brassica campestris cv.YST-151 and Brassica campestris cv. PT-30 were taken. Each Brassica species was treated as one treatment. Sowing of different oilseed Brassica was done on $10^{\text {th }}$ November in both the years, 2008 and 2009. The plot size of $5 \mathrm{~m} \times 3 \mathrm{~m}$ was maintained with row to row and plant to plant distances of 30 and $10 \mathrm{~cm}$ respectively. During experimentation all the recommended cultural practices were followed to raise the healthy crop except plant protection measures. Daily and weekly average data on maximum temperature, rainfall, relative humidity, sunshine hours, wind velocity and evaporation prevailed during the course of present study were recorded at meteorological observatory of this University.

Insect sampling: Field surveillance was regularly carried out from crop sowing to maturity at weekly intervals to record appearance of mustard aphids and natural enemies. At pest appearance, data on the incidence of L. erysimi and different natural enemies viz. Coccinellid adults and grubs, syrphid fly larvae and number of parasitized/mummified aphids were recorded at weekly intervals from 5 plants selected randomly. The sampling methods used to assess the number of L. erysimi and different predators involved whole plant visual inspection (Patel et al., 2004). All life stages of different natural enemies were recorded on whole plant basis. The immature stages were brought to the laboratory to develop to adult stage for their accurate identification. All the natural enemies were identified up to species level.

Observation on the percent field parasitization of mustard aphid by the parasitoid Diaeretiella rapae was also recorded in the mustard field by counting the number of healthy and mummified (parasitized) aphids from selected tagged plants of each variety. Percent parasitization was worked out according to the formula as given by Root and Skelsey (1969).

$$
\text { Per cent parasitization }=\frac{\text { Number of parasitized aphids }}{\begin{array}{l}
\text { Total number of aphids } \\
\text { (healthy and parasitized) }
\end{array}} \times 100
$$

Statistical analysis: Randomized block design (RBD) was used to compute the variance. The correlation was also worked out between environmental parameters (maximum and minimum $(0 \mathrm{C})$ temperature, relative humidity, rainfall $(\mathrm{mm})$, wind velocity $(\mathrm{Km} / \mathrm{h})$, sunshine hours) and the population of Coccinellids, syrphid larvae and per cent parasitization under field conditions.

\section{RESULTS AND DISCUSSION}

Population dynamics of Coccinellids (Coleoptera: Coccinellidae) on different cultivars of rapeseedmustard: In both the years the activity of coccinellids was initiated during $4^{\text {th }}$ standard week on all cultivars except T-27, Sheetal, CCN-06-1 and PBR-1 and continued till $10^{\text {th }}$ week except PT-30. After the initiation of activity, on all cultivars the population of coccinellids in both the years gradually increased, attained maximum population $\left(9^{\text {th }}\right.$ standard week in $2008-09$ and $8^{\text {th }}$ standard week in 2009-10) followed by a decline (Table 2).

In 2008-09 maximum population of coccinellids was observed in $9^{\text {th }}$ standard week on all cultivars except

Table 1. Population buildup of L. erysimi on different cultivars of rapeseed-mustard under field conditions.

\begin{tabular}{lccccccc}
\hline \multicolumn{7}{c}{ Average number of aphid population per 10 cm central twig during standard weeks on 9 cultivars } \\
\hline \multicolumn{7}{c}{$\mathbf{2 0 0 8 - 0 9}$} \\
$\begin{array}{l}\text { Standard } \\
\text { week }\end{array}$ & Pooled mean & S. Em & CD at 5\% & $\begin{array}{c}\text { Standard } \\
\text { week }\end{array}$ & Pooled mean & S. Em & CD at 5\% \\
\hline 04 & 117.17 & 3.82 & 11.48 & 04 & 132.79 & 6.01 & $18.02^{* *}$ \\
05 & 143.88 & 5.17 & 15.51 & 05 & 162.30 & 3.75 & $11.26^{* *}$ \\
06 & 149.89 & 5.73 & 17.20 & 06 & 189.35 & 3.63 & $10.88^{* *}$ \\
07 & 107.98 & 9.60 & 28.19 & 07 & 171.90 & 4.23 & $12.68^{* *}$ \\
08 & 71.44 & 3.92 & 11.72 & 08 & 139.45 & 4.05 & $12.15^{* *}$ \\
09 & 30.07 & 3.25 & 9.75 & 09 & 99.12 & 3.26 & $9.77^{* *}$ \\
10 & 6.47 & 1.40 & 4.22 & 10 & 12.22 & 1.13 & $3.40^{* *}$ \\
\hline
\end{tabular}


Richa Varshney et al. / J. Appl. \& Nat. Sci. 9 (1): 10 -18 (2017)

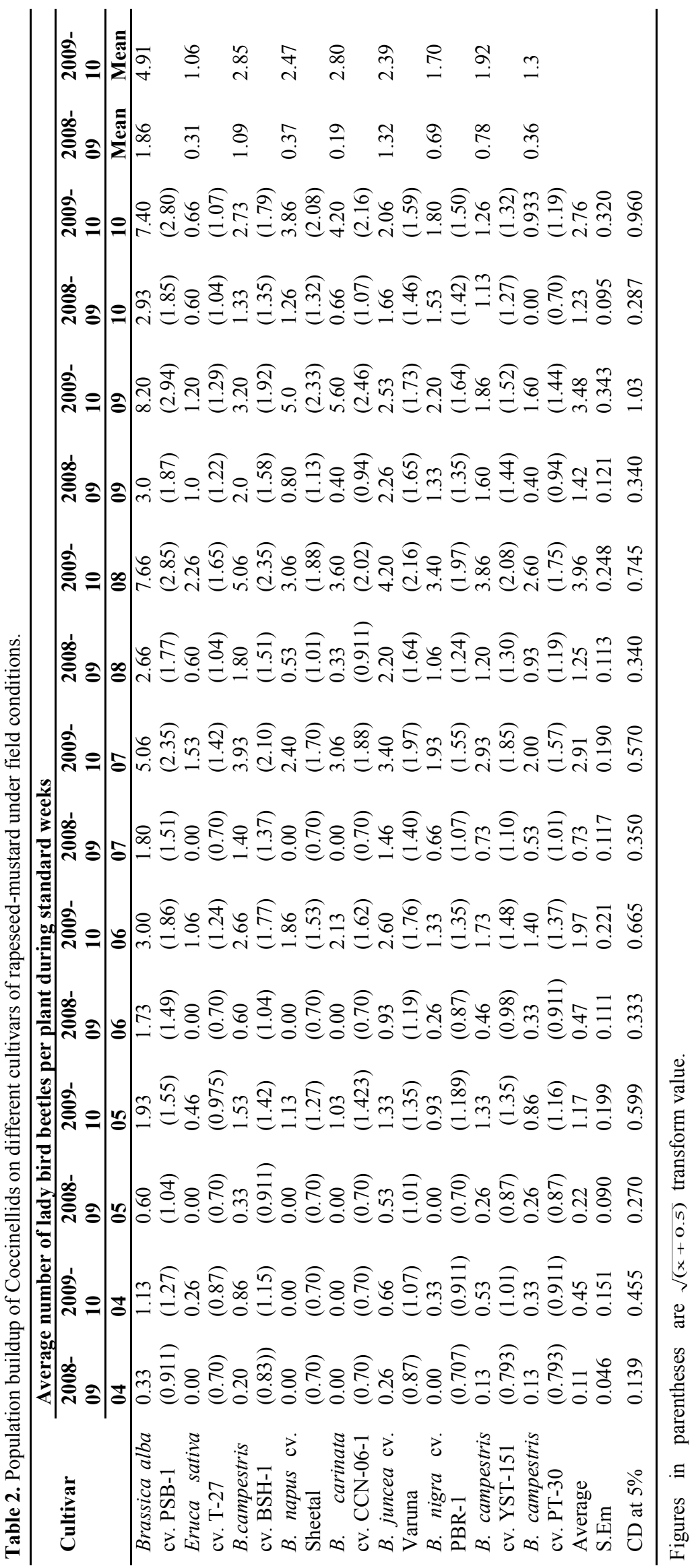


Richa Varshney et al. / J. Appl. \& Nat. Sci. 9 (1): 10 -18 (2017)

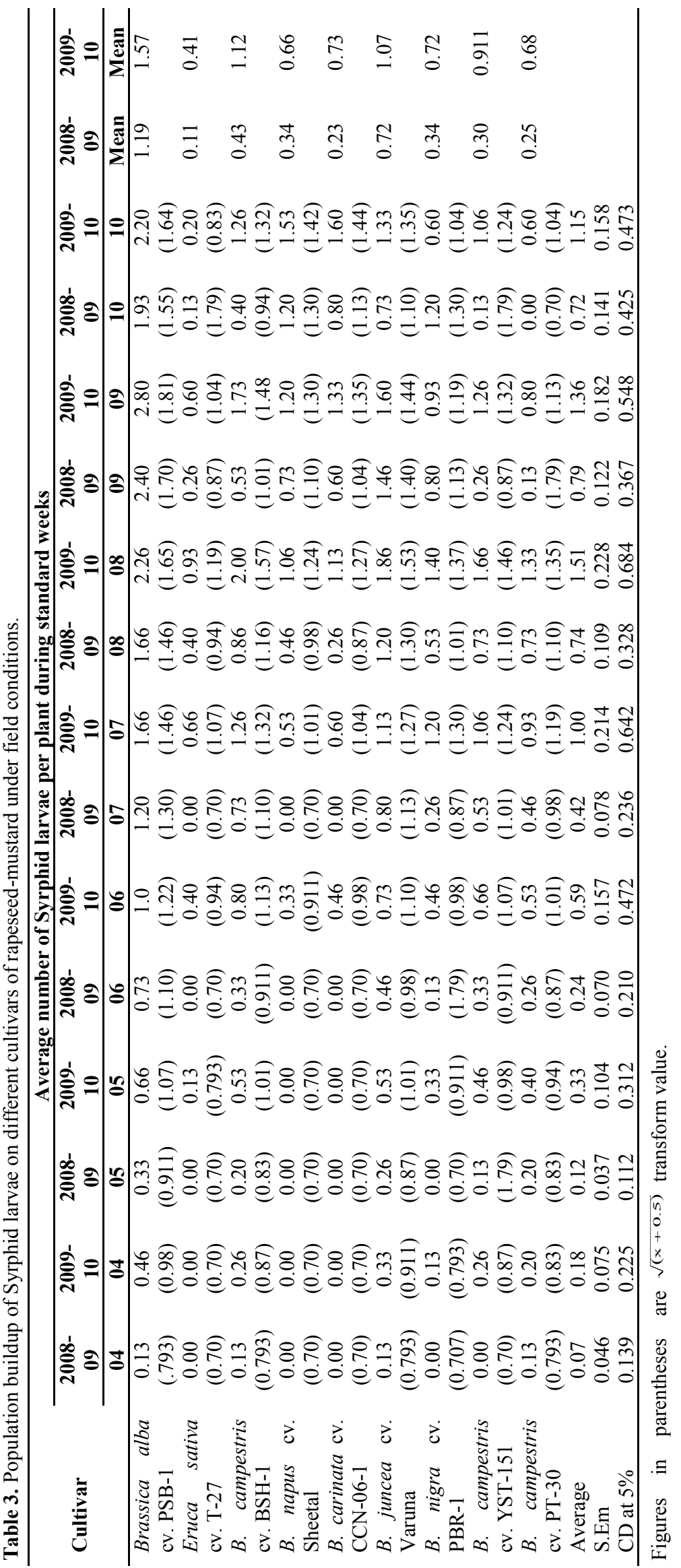


Richa Varshney et al. / J. Appl. \& Nat. Sci. 9 (1): 10 -18 (2017)

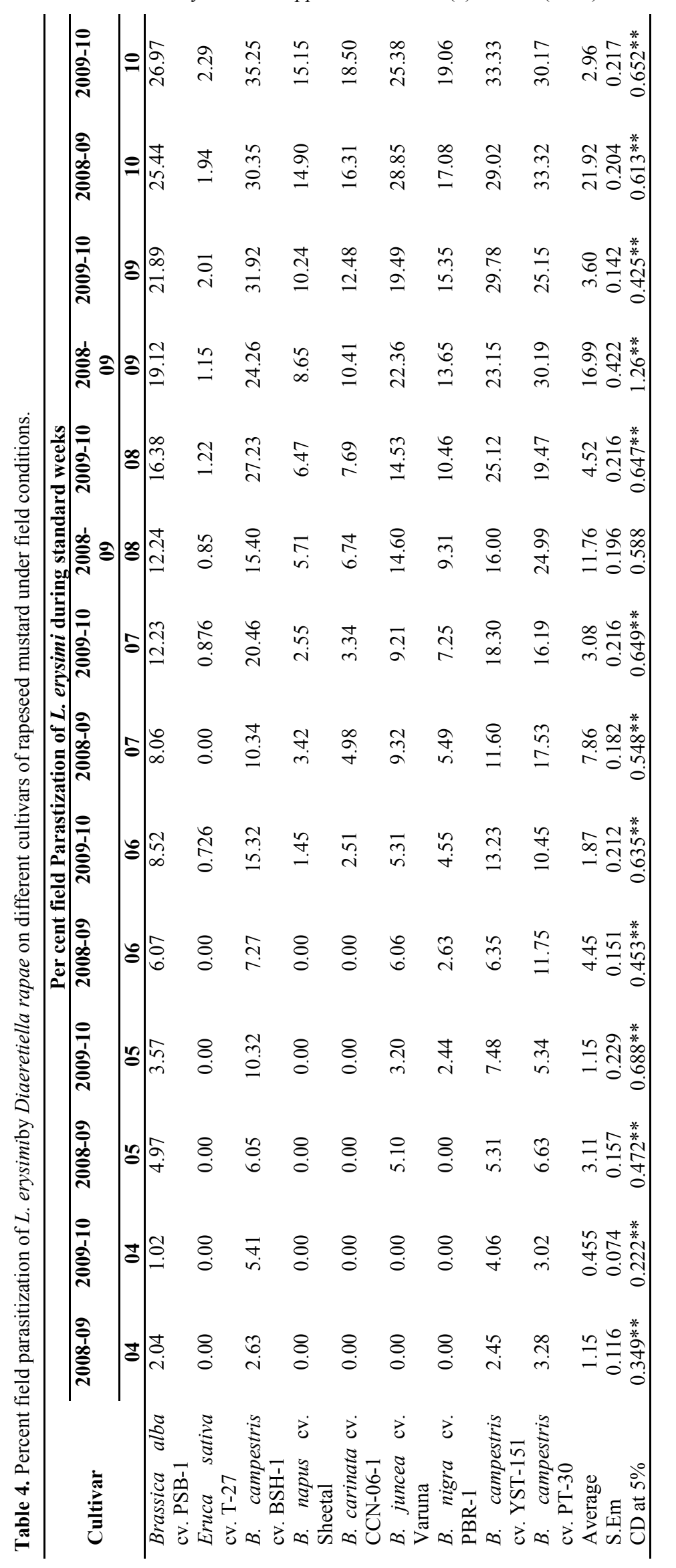


Richa Varshney et al. / J. Appl. \& Nat. Sci. 9 (1): 10 -18 (2017)

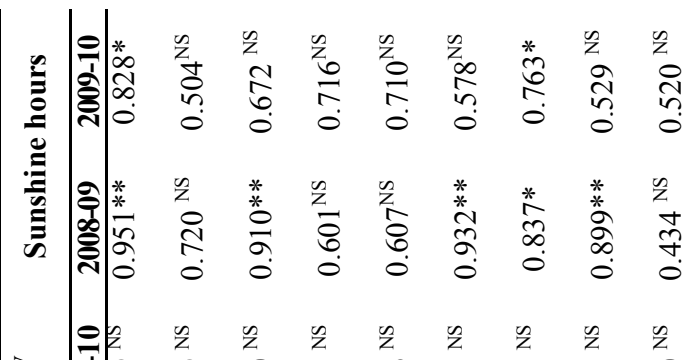

=

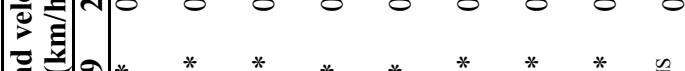

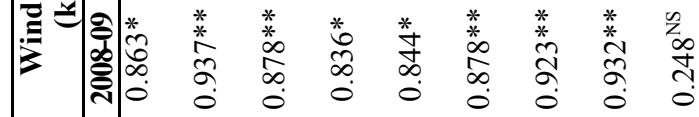

营

$\begin{array}{lllllllll}n & n & n & n & n & n & n & n & n \\ 0 & n & \bar{n} & 0 & n & + & \tilde{0} & 0 & n\end{array}$

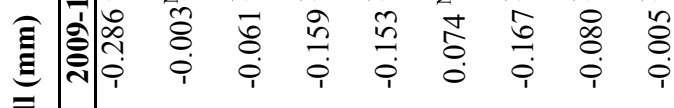

总

宽

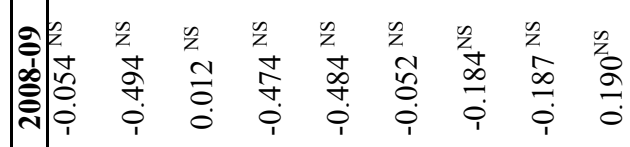

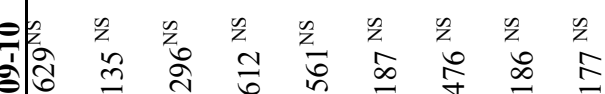

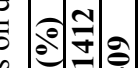

嵌

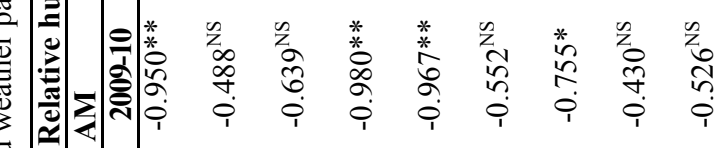

ปิ)

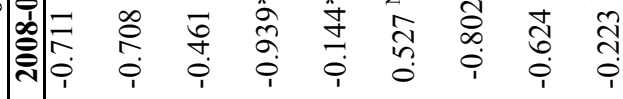
|

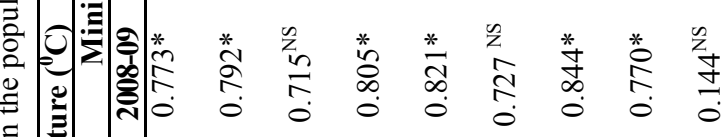

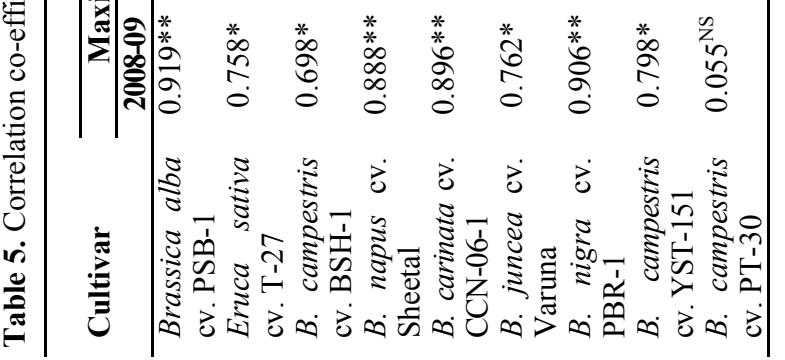

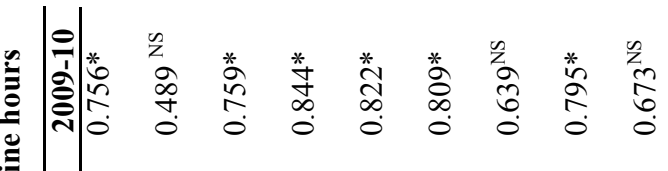

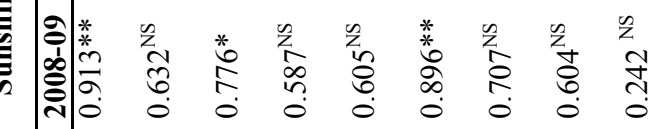

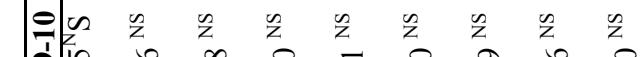

•

हो

离

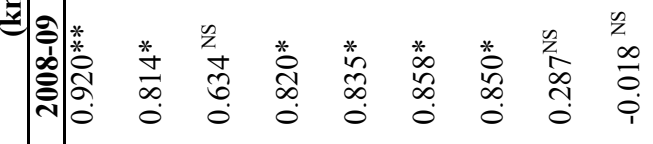

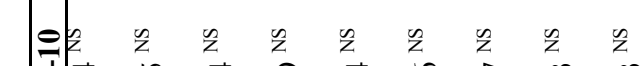

हี

焉

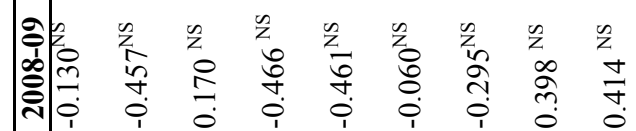

苞|

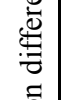

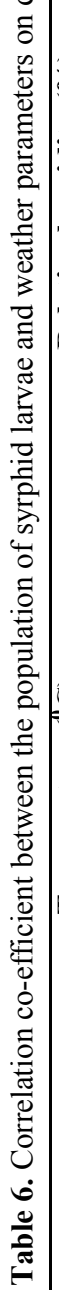

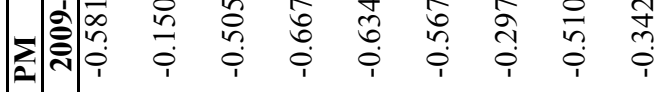

จิ

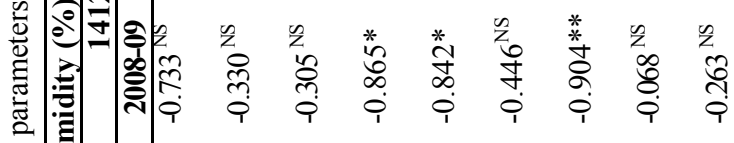

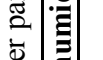

党 蛋

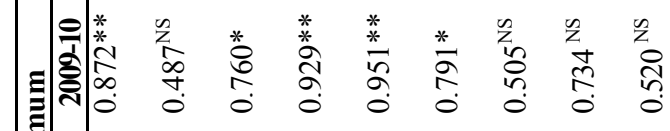
客泀|

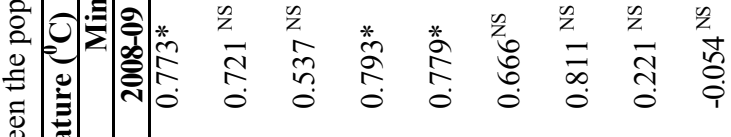

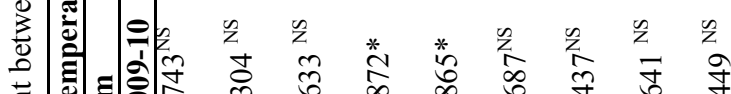
武

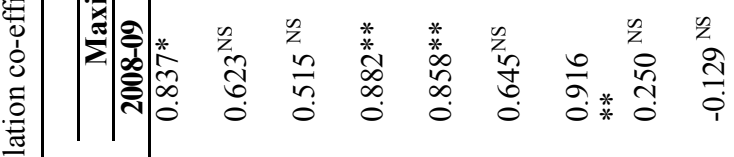
竞

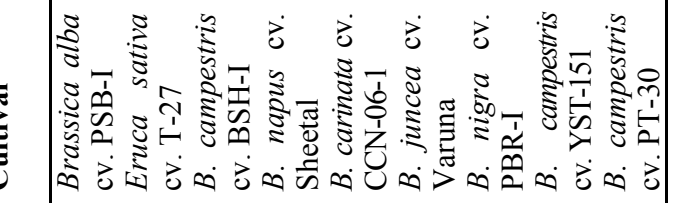


Sheetal, CCN-06-1,PBR-1 and PT-30 while the peak activity of mustard aphid was recorded from $6^{\text {th }}-9^{\text {th }} \mathrm{SW}$ on most of the cultivars. In $8^{\text {th }}$ standard week, during 2008-09 PT-30 showed peak coccinellids activity (0.93 coccinellids/ plant) followed by decline. Similarly in $9^{\text {th }}$ SW, PSB-1, T-27, BSH-1, Varuna and YST-151 (3.00,1.00, 2.00, 2.26 and 1.60 coccinellids/ plant) exhibited peak coccinellids activity while Sheetal (1.26 coccinellids/ plant), PBR-1(1.53 coccinellids/ plant) and CCN-06-1 (0.66 coccinellids/ plant) showed peak activity of coccinellids in $10^{\text {th }} \mathrm{SW}$ followed by decline. The first appearance of coccinellids on Sheetal, T-27 and CCN-061 was noticed during $8^{\text {th }}$ standard week with $0.53,0.60$, and 0.33 coccinellids/ plant respectively. In 2009-10, peak activity of coccinellids was observed in $8^{\text {th }}$ standard week on all cultivars except PSB-1, Sheetal and CCN-06-1 which showed peak activity in $9^{\text {th }} \mathrm{SW}$ while the peak activity of mustard aphid was recorded from $6^{\text {th }}-9^{\text {th }} \mathrm{SW}$ on most of the cultivars. It is clear that the population dynamics of coccinellids beetles indicated that its population increased gradually with the increase of aphid population and decreased gradually with the decrease in aphid population. Similar results were observed by Soni et al., 2013 and Khan et al. (2011) who reported that $C$. septempunctata populations in wheat had a strong positive and significant correlation with the aphid numbers in the field.

The present finding are in close agreement with Kulkarni and Patel (2001) reported that population of lady bird beetles appeared during the last week of January $\left(5^{\text {th }} \mathrm{SW}\right)$, attained peak during the third week of February $\left(8^{\text {th }} \mathrm{SW}\right)$ and thereafter, it declined in last week of February $\left(9^{\text {th }} \mathrm{SW}\right)$. While Singh et al. (2006) observed that population of Coccinella septempunctata started from 9th week, after sowing of the crop. Thereafter, the populations of this predator gradually increased and attained peak on the 2 March.

Population dynamics of syrphid larvae on different cultivars: The perusal of data depicted in Table 3 revealed in both the years that the first appearance of syrphid larvae on the cultivars occurred in $4^{\text {th }}$ standard week except few cultivars. After the initiation of activity, on all cultivars the population of syrphid larvae in both the years gradually increased, attained maximum population $\left(8^{\text {th- }} 10^{\text {th }}\right.$ standard weeks in both the years) followed by a decline on respective cultivar. The peak activity of mustard aphid was recorded from $6^{\text {th }}-9^{\text {th }} \mathrm{SW}$ on most of the cultivars.

In $8^{\text {th }}$ standard week, during 2008-09 maximum syrphid population was recorded on PSB-1 (1.66 syrphids/plant with aphid population 224.20) followed by Varuna (1.20 syrphids/plant with aphid population 48.06), BSH-1 (0.86 syrphids/plant with aphid population 126.23), YST-151(0.73 syrphids/plant with aphid population 102.67), PT-30 (0.60 syrphids/plant with aphid population 63.87) and PBR-1(0.53 syrphids/ plant with aphid population 14.33). PSB-1 (2.40 syr- 
phids/plant) and Varuna (1.46 syrphids/plant) exhibited highest syrphid population in $9^{\text {th }} \mathrm{SW}$ while Sheetal, CCN-06-1 and PBR-1 exhibited highest syrphid population $\left(1.20,0.80\right.$ and 1.20 syrphids/plant) in $10^{\text {th }} \mathrm{SW}$. first appearance of syrphid population on T-27, Sheetal and CCN-06-1 was noticed during $8^{\text {th }}$ standard week (Table 3). During 2009-10, in $8^{\text {th }}$ standard week the cultivars BSH-1, Varuna, YST-151, PBR-1, PT-30 and T-27 exhibited maximum syrphid population (2.00, $1.86,1.66,1.40,1.33$ and 0.93 syrphids/plant, respectively) followed by a declining trend of larvae population. Highest syrphid population (2.80 syrphids/plant) on PSB-1 was observed during 9th SW while CCN-061 and sheetal exhibited highest syrphid population (1.60 and 1.53 syrphids/plant) in $10^{\text {th }} \mathrm{SW}$. (Table 3 ). Devi et al. (2011) reported that syrphids attained maximum population in $6^{\text {th }} \mathrm{SW}$ which is coincided with the maximum population of aphids and then gradually decreased. Our findings are in close conformity with Kulkarni and Patel (2001) and Vekaria and Patel (2005) who observed that the activity of syrphid larvae started during 4th SW and lasted up to the 9th SW.

Per cent field parasitization of mustard aphid by the parasitoid, Diaeretiella rapae on different cultivars in different standard weeks: Appearance of parasitized aphids occurred from $4^{\text {th }}$ standard week, at flowering stage of the crop increased gradually in the following weeks, and attained peak parasitization in the $10^{\text {th }}$ standard week at maturity stage of the crop. Nevertheless, the extent of parasitization varied with respect to different cultivars and ecological conditions in different years. Thus among all the cultivars maximum aphid parasitization during 2008-09 in the present study was recorded with PT$30(33.32 \%)$ followed by BSH-1, YST-151, Varuna, PSB1, PBR-1, CCN-06-1, Sheetal and T-27 (30.35, 29.02, $28.85,25.44,17.08,16.31,14.90$ AND 1.94\%, respectively) while during 2009-2010 it was maximum with BSH-1 (35.25\%) followed by YST-151, PT-30, PSB-1, Varuna, PBR-1, CCN-06-1, Sheetal and T-27 (33.33, 30.17, 26.97, $25.38,19.06,18.50,15.15$ and $2.29 \%$, respectively) (Table 4).The present findings are in close agreement with Dogra et al. (2003) and Raj and Lakhanpal (1998) who reported the first appearance of $D$. rapae on L.erysimi in the field occurred during the second week of January which gradually increased and attained maximum parasitization $(51.07 \%)$ in the second or first week of March.

It was evident from the study that during both the years mustard aphid started appearing from 51st SW on all cultivar except few and peak activity of mustard aphid was observed in 6 th $-9^{\text {th }} \mathrm{SW}$ on most of the cultivars while predators activity was started from $4^{\text {th }} \mathrm{SW}$ and peak was observed from 8 th week onwards. Highest $\%$ parasitization observed in $10^{\text {th }} \mathrm{SW}$ at the maturity of crop. In the present study, coccinellids were the predominant natural enemies. There were changes in the abundance of natural enemies in different cultivars through the years as well as among cultivars within a year. There may be different causes like climate (Rotheray and Gilbert, 2011), prey density on different cultivars (Thalji, 2006), insolation, quality of host plants (Alhmedi et al., 2009), and adjacent habitats (Alhmedi et al., 2009; Vandereycken et al., 2013). Straub and Snyder (2006) demonstrated that coccinellids are the key species in a natural enemy guild in organic brassica fields in Canada and cabbage aphid, Brevicoryne brassicae.

Coccinellids, syrphid larvae and parasitoid exhibited positive correlation with maximum and minimum temperatures, wind velocity and sunshine hours in most of the all cultivars. Population of bioagents exhibited negative correlation with morning and evening relative humidity and rainfall on all cultivars in both the years of study (Tables 5-7). The reason for this negative correlation could possibly be due to the fact that population of natural enemies did not synchronize with respective parameters. These abiotic factors influence the growth of insects which further depends on their thermal requirements and host specificity.

\section{Conclusion}

From the present study, it can be concluded that the activity and the population density of aphidophagous insects in particular varied with the different standard weeks (with varied ecological conditions) and with cultivars. The aphid attained marked higher population on most of the cultivars during $6^{\text {th }} \mathrm{SW}$ (pooled mean 149.89 aphids $/ 10 \mathrm{~cm}$ apical shoot during 200809 and 189.35 aphids $/ 10 \mathrm{~cm}$ apical shoot during 2009$10)$, in both the years followed by higher coccinellids (pooled mean 1.42/plant in $9^{\text {th }} \mathrm{SW}$ and $3.96 /$ plant in $8^{\text {th }}$ SW during 2008-09 and 2009-10 respectively) and syrphid population (pooled mean $0.122 /$ plant in $9^{\text {th }} \mathrm{SW}$ and $0.228 /$ plant in $8^{\text {th }}$ SW during 2008-09 and 200910 respectively). To make biological control of mustard aphid more effective and efficient, we should also promote conservation of natural enemies by providing alternative and essential food for natural enemies and by avoiding/delaying spray of insecticides especially early in the season. Regular monitoring should be done if, natural enemies population is less initially, they can be released in field so that aphid population can be managed effectively.

\section{ACKNOWLEDGEMENTS}

The authors are highly thankful to the Head of Department Entomology, GBPUA\&T, Pantnagar, for providing Laboratory facilities.

\section{REFERENCES}

Agricultural Statistics at a glance, (2014). Directorate of Economics and Statistics, Department of Agriculture and Cooperation, Ministry of Agriculture, Government of India, New Delhi. Oxford University press. 
Alhmedi, A., Haubruge, E. and Francis, F. (2009). Effect of Stinging Nettle Habitats on Aphidophagous Predators and Parasitoids in Wheat and Green Pea Fields with Special Attention to the Invader Harmonia axyridis Pallas (Coleoptera: Coccinellidae). Entomol. Sci., 12(4): 349-358

Atri, C., Kumar, B., Kumar, H., Kumar, S., Sharma, S. and Banga, S. S. (2012). Development and Characterization of Brassica juncea-fruticulosa Introgression Lines Exhibiting Resistance to Mustard Aphid, Lipaphis erysimi (Kalt.) BMC Genetics, 13: 104. doi: 10.1186/1471-2156 $-13-104$

Bhatia, V., Uniyal, P. L. and Bhattacharya, R. (2011). Aphid Resistance in Brassica Crops: Challenges, Biotechnological Progress and Emerging Possibilities. Biotechnol. $A d v ., \quad 29: \quad 879-888 . \quad$ DOI: $10.1016 / j$.biotechadv. 2011.07.005

Dogra, I., Devi, N. \& Desh-Raj. (2003). Parasitization of mustard aphid, Lipaphis erysimi Kalt.by Diaeretiella rapae M'Intosh in the mid-hill zone of Himachal Pradesh (India). Journal of Entomological Research, 27: 145-149

Golizadeh, A., Kamali, K., Fathipour, Y. and Abbasipour, H. (2009). Life Table of the Diamondback Moth, Plutella xylostella (L.) (Lepidoptera: Plutellidae) on Five Cultivated Brassicaceous Host Plants. J. Agric. Sci. Technol., 11: $115-124$

Hong, C. P., Kwon, S. J., Kim, J. S., Yang, T. J., Park, B. S. and Lim, Y. P. (2008). Progress in Understanding and Sequencing the Genome of Brassica rapa. Int. J. Pl. Genomics, DOI: 10.1155/2008/582837

Khan, A.A., Khan, A.M., Tahir, H.M., Afzal, M., Khaliq, A., Khan, S.Y. and Raza, I. (2011). Effect of wheat cultivars on aphids and their predator populations. African J. Biotech., 10:18399-18402

Kulkarni, A.V. and Patel, I.S. (2001). Seasonal abundance of mustard aphid (Lipaphis erysimi) and associated bioagents in Indian mustard (Brassica juncea) crop. Indian Journal of Agricultural Science, 71(10): 681-682

Kumar, S. (2015). Relative Abundance of Turnip Aphid and the Associated natural enemies on Oilseed Brassica Genotypes. J. Agr. Sci. Tech., 17: 1209-1222

Kumar, S., Atri, C., Sangha, M. K. and Banga, S. S. (2011). Screening of Wild Crucifers for Resistance to Mustard Aphid, Lipaphis erysimi (Kaltenbach) and Attempt at Introgression of Resistance Gene(s) from Brassica fruticulosa to Brassica juncea. Euphytica, 179: 461470.DOI: 10.1007/s10681-011-0351-z.

Patel, S. R., Awasthi, A. K. and Tomar, R. K. S. (2004). Assessment of Yield Losses in Mustard (Brassica juncea L.) due to Mustard Aphid (Lipaphis erysimi Kalt.)under Different Thermal Environments in Eastern Central India. Appl. Ecol. Environ. Res., 2: 1-15
Raj, Desh and Lakhanpal, G.C. (1998). Efficiency of endoparasitoid Diaeretiella rapae (M'Intosh) on aphid complex infesting rapeseed in mid hill zone of Himachal Pradesh (India). J. ent. Res., 22 (3): 245-251.

Root BR, Skelsey (1969). Biotic factors involved in crucifer aphid outbreaks following insecticides application. $J$. Econ. Entomol., 62(1): 223-233

Rotheray, G. and Gilbert, F. S. (2011). The Natural History of Hoverflies. Forrest Text, Camarthen, Swny Nant., xiv333p.

Singh, A.P.; Singh, P.P. and Singh, Y.P. (2006). Biology of mustard aphid, Lipaphis erysimi kalt. Indian Journal of Entomology, 68(2): 144-147

Singh, K., Singh, N.N. and Raju, S.V.S. (2012). Feidng Potential of grubs and,larvae of Syrphid and Coccinellid predators on mustard aphid Ind. J. of Pl. Prot., 40(2): 157-159

Singh, K. (2013). Preying Propensity of Larvae/ Grubs of Syrphid and Coccinellid Predators on Mustard aphid Lipaphis erysimi (KALT.). International Journal of Agriculture and Food Science Technology, 4(7):687-694

Soni, R., Deol, G.S. and Singh, S. (2013). Seasonal dynamics of wheat aphid complex and predator Coccinella septempunctata in relation to abiotic and biotic factors. Journal of Environmental Biology, 34: 689-694

Straub, C. S. and Snyder, W. E. (2006). Species Identity Dominates the Relationship between Predator Biodiversity and Herbivore Suppression. Ecol., 82: 277-282

Suwabe, K., Tsukazaki, H., Iketani, H., Hatakeyama, K., Kondo, M., Fujimura, M., Nunome, T., Fukuoka, H., Hirai, M. and Matsumoto, S. (2006). Simple Sequence Repeat-based Comparative Genomics between Brassica rapa and Arabidopsis thaliana: The Genetic Origin of Clubroot Resistance. Genetics, 173: 309-319

Thalji, R. (2006). Composition of Coccinellids Communities in Sugar Beet Fields in Vojvodina. Zbornik Matice Srpske za Prirodne Nauke., 110: 267-273

Trdan, S., Milevoj, L., Žežline, I., Raspudič, E., Anđus, L., Vidrih, M., Bergant, K., Valič, N. and Žnidarčič, D. (2005). Feeding Damage by Onion Thrips, Thrips tabaci Lindeman (Thysanoptera, Thripidae), on Early White Cabbage Grown under Insecticide-free Conditions. African Entomol., 13: 85-95

Vandereycken, A., Durieux, D., Joie, E., Sloggett, J. J., Haubruge, E. and Verheggen, F. J. (2013). Is the Multicolored Asian Ladybeetle (Harmonia axyridis) the Most Abundant Natural Enemy to Aphids in Agroecosystems? J. Insect Sci., 13: 158. Available Online:http:// www.insectscience.org/13.158

Vekaria, M.V. and Patel, G.M. (2005). Seasonal abundance of Lipaphis erysimi (Kalt.) and their natural enemies on important cultivars of mustard in North Gujarat. Indian Journal of Entomology, 67(4): 369-377. 